\title{
Abstracts, Poster Presentations P22 - P35
}

Published online: 14 January 2004

(C) Springer-Verlag 2004

Eur J Nucl Med Mol Imaging (2004) 31:459

DOI 10.1007/s00259-003-1433-5

\section{Eur J Nucl Med Mol Imaging (2003) 30:S301-S340}

Please note that in the published abstract No. 491 "Polyethyeneiminomethyl phosphonate (PEI-MP) for selectively targeting bone malignancies" only the first author was given. The complete and correct list of authors is as follows:

M.F. Botelho, J.R. Zeevaart, W.K.A. Louw, I.C. Dormehl, Z. Kolar, C. Gomez, L. Metello, A. Abrunhosa, R.J. Milner, F.H.A. Schneeweiss, J.J.Pedroso de Lima

Address correspondence to: idormehl@medic.up.ac.za

The online version of the original article can be found at http://dx.doi.org/10.1007/s00259-003-1286-y 